\title{
Using RT-PCR assay for the detection of Brome mosaic virus (BMV) in cereal leaf beetle (Oulema melanopus L.)
}

\section{Zastosowanie techniki RT-PCR do wykrywania wirusa mozaiki stokłosy (Brome mosaic virus, BMV) w skrzypionce zbożowej (Oulema melanopus L.)}

\author{
Katarzyna Trzmiel ${ }^{1 *}$, Beata Wielkopolan ${ }^{2}$, Marzena Lewandowska ${ }^{3}$
}

\begin{abstract}
Summary
Brome mosaic virus (BMV) is spherical virus belonging to Bromovirus genera in Bromoviridae family. In Poland the virus was detected and described for the first time in wheat (Triticum aestivum L.) in 1997. In 2013 its presence was confirmed in triticale ( $x$ Triticosecale Wittm. ex A. Camus) and for the first time in maize (Zea mays L.). BMV is transmitted by vectors: mainly beetles (several species of Oulema and Phylotrella genera) and mechanically. The virus induce leaf mosaic of infected plants and reduce plant height and weight. The incidence of the disease is closely correlated with the beetles number. The existing literature data do not contain any information on the vectors infectivity in Poland. The specific primers and RT-PCR (reverse transcription-polymerase chain reaction) conditions were developed for the detection of BMV in its vector - cereal leaf beetle (Oulema melanopus L.). They can be used in the studies on the evaluation of caught beetles infectivity which will allow estimate the real risk of the disease.
\end{abstract}

Key words: BMV; RT-PCR; vector; detection

\section{Streszczenie}

Wirus mozaiki stokłosy (Brome mosaic virus, BMV) jest sferycznym wirusem należącym do rodzaju Bromovirus w rodzinie Bromoviridae. W Polsce wirus ten po raz pierwszy wykryto i opisano w pszenicy w 1997 roku, a w 2013 roku jego obecność potwierdzono w pszenżycie i po raz pierwszy w kukurydzy. Wirus jest przenoszony przez wektory, głównie skrzypionki (kilka gatunków z rodzajów: Oulema i Phylotrella) oraz mechanicznie. Powoduje mozaikę liści, obniżenie wzrostu i masy porażonych roślin. Nasilenie występowania choroby jest ściśle skorelowane z liczebnością skrzypionek. Dotychczasowe dane literaturowe nie zawierają informacji na temat infekcyjności wektorów na terenie Polski. Dzięki opracowaniu specyficznych starterów oraz warunków reakcji odwrotnej transkrypcji i łańcuchowej polimerazy (RT-PCR - reverse transcription-polymerase chain reaction), wykazano przydatność tej techniki do wykrywania BMV w jego wektorze - skrzypionce zbożowej (Oulema melanopus L.). Może ona być wykorzystywana w badaniach nad oceną infekcyjności odłowionych skrzypionek, co pozwoli oszacować realne zagrożenia wystąpienia choroby.

Słowa kluczowe: BMV; RT-PCR; wektor; wykrywanie

Instytut Ochrony Roślin - Państwowy Instytut Badawczy

Władysława Węgorka 20, 60-318 Poznań

${ }^{1}$ Zakład Wirusologii i Bakteriologii

2ZZakład Metod Prognozowania Agrofagów i Ekonomiki Ochrony Roślin

${ }^{3}$ Bank Patogenów Roślin i Badania ich Różnorodności

*corresponding author: K.Trzmiel@iorpib.poznan.pl 


\section{Wstęp / Introduction}

$\mathrm{Na}$ plantacjach zbóż w Polsce pojawia się wiele agrofagów mających duży wpływ na obniżenie plonu. Do tej grupy, oprócz mszyc (Aphididae) oraz lokalnie pryszczarka zbożowca (Haplodiplosis equestris, Wagner), zalicza się chrząszcze $\mathrm{z}$ rodziny stonkowatych (Chrysomelidae) - skrzypionki (Oulema spp.) (Walczak i wsp. 1987). Na terenie naszego kraju występują dwa gatunki skrzypionek, tj. skrzypionka zbożowa (Oulema melanopus, Linnaeus 1758) oraz skrzypionka błękitek (Oulema gallaeciana, Heyden 1870). Zarówno larwy, jak i chrząszcze niszczą liście zbóż (Walczak i wsp. 1999), co ma istotny wpływ na jakość i ilość uzyskiwanego plonu (Kostov 2001). Głównym stadium szkodliwym są larwy. Szacuje się, że ostatnie stadium larwalne jest odpowiedzialne za $70 \%$ szkód. Żerowanie na liściu flagowym ma największy wpływ na plon (Wilson i wsp. 1969). Straty w plonie będące wynikiem żerowania skrzypionek, szacuje się w granicach od 3 do $8 \%$ w Polsce (Ulrich i wsp. 2004), $70 \%$ w centralnej Europie (Stilmant 1995) do 95\% w Holandii (Daamen i Stol 1993). Szkodliwość skrzypionek zbożowych wynika zarówno $\mathrm{z}$ mechanicznego uszkadzania roślin, jak i z przenoszenia i zakażania zbóż oraz dziko rosnących traw wirusem mozaiki stokłosy (Brome mosaic virus, BMV).

BMV jest sferycznym wirusem należącym do rodzaju Bromovirus w rodzinie Bromoviridae. Jego występowanie potwierdzono w USA, Europie oraz południowej części Afryki (Lane 1977). W Polsce BMV wykryto i opisano w pszenicy w 1997 roku (Jeżewska i Wieczorek 1999), a w 2013 roku jego obecność potwierdzono w pszenżycie (Trzmiel i wsp. 2015) i po raz pierwszy w kukurydzy (Trzmiel i wsp. 2015, nieopublikowane). Wirus łatwo przenosi się mechanicznie oraz przez wektory (Szabolcs i Gáborjányi 1991), powoduje mozaikę liści, obniżenie wzrostu i masy porażonych roślin (Pocsai 1987). Nasilenie występowania choroby jest ściśle skorelowane z liczebnością skrzypionek (Mise i Pocsai 2004). Dotychczasowe dane literaturowe nie zawierają informacji na temat infekcyjności wektorów na terenie Polski.

Celem pracy było opracowanie czułej i wiarygodnej techniki diagnostycznej opartej na reakcji odwrotnej transkrypcji i łańcuchowej polimerazy (reverse transcrip- tion-polymerase chain reaction - RT-PCR) z użyciem zaprojektowanych par specyficznych starterów.

\section{Materiały i metody / Materials and methods}

W doświadczeniu wykorzystano 20 larw skrzypionek zebranych $\mathrm{z}$ roślin jęczmienia w Winnej Górze (województwo wielkopolskie) w czerwcu 2014 roku. Na uprawach nie stwierdzano objawów infekcji wirusowych. W badaniach używano imago skrzypionki zbożowej. Materiał wirusowy zebrano w 2013 roku z roślin kukurydzy z objawami systemicznej mozaiki liści oraz zahamowaniem wzrostu (okolice Środy Wielkopolskiej), stanowił go izolat BMV (BMV-Sr). Wirus utrzymywano i namnażano w warunkach szklarniowych, poprzez mechaniczną inokulację roślin jęczmienia ozimego odmiany Bażant.

W ramach prowadzonych badań, w celu nabycia wirusa, 5 pojedynczych dorosłych osobników skrzypionki zbożowej nakładano na $24 \mathrm{~h}$ na porażone rośliny jęczmienia, następnie zbierano i zabezpieczano w 70\% etanolu w temperaturze $-20^{\circ} \mathrm{C}$.

Całkowity RNA z 3 pojedynczych skrzypionek izolowano przy użyciu zestawu Total RNA Purification Kit (3-zone \& RNA purification columns) firmy Novazym (Polska) zgodnie $\mathrm{z}$ procedurą dostarczoną przez producenta.

Amplifikację fragmentów genomu BMV prowadzono z użyciem trzech par specyficznych starterów, odpowiednio dla RNA1, RNA2 oraz białka płaszcza (coat protein CP) kodowanego przez subgenomowe RNA4 wirusa (tab. 1). Do projektowania starterów wykorzystano program Primer3 (http://frodo.wi.mit.edu/primer3) (Rosen i Skaletski 2000).

W jednoetapowej reakcji RT-PCR wykorzystano zestaw OneStep RT-PCR firmy Qiagen (Niemcy). Mieszaninę reakcyjną o końcowej objętości $10 \mu \mathrm{l}$ przygotowywano zgodnie z zaleceniami producenta. Jako kontroli pozytywnej używano próby z RNA BMV-Sr, natomiast kontrolę negatywną stanowiły próby bez matrycy. Reakcje prowadzono w następujących warunkach termicznych: odwrotna transkrypcja przez $30 \mathrm{~min}$ w $50^{\circ} \mathrm{C}$, dezaktywakcja transkryptazy i jednoczesna aktywacja polimerazy HotStar Taq DNA w $95^{\circ} \mathrm{C}$ przez 15 min, 40 cykli (denaturacja:

Tabela 1. Startery wykorzystane do amplifikacji fragmentów RNA1, RNA2 i sgRNA4 BMV

Table 1. Primers used for amplification of BMV RNA1, RNA2 and sgRNA4 fragments

\begin{tabular}{|c|c|c|c|c|}
\hline $\begin{array}{l}\text { Starter } \\
\text { Primer }\end{array}$ & $\begin{array}{l}\text { Pozycja* } \\
\text { Position }\end{array}$ & $\begin{array}{l}\text { Sekwencja starterów } 5^{\prime}-3 \text { ' } \\
\text { Primer sequence } 5{ }^{\prime}-3{ }^{\prime}\end{array}$ & $\begin{array}{c}\text { Temperatura } \\
\text { anilingu } \\
\text { Annealing } \\
\text { temperature } \\
\mathrm{T}_{\mathrm{a}}\end{array}$ & $\begin{array}{c}\text { Wielkość produktu } \\
{[\mathrm{pz}]} \\
\text { Amplicon size } \\
{[\mathrm{bp}]}\end{array}$ \\
\hline BMV1-F & $858-878$ & GAGTCGGTGCATTGCATCGAT & \multirow{2}{*}{$55^{\circ} \mathrm{C}$} & \multirow{2}{*}{830} \\
\hline BMV1-R & $1681-1661$ & ACGGACTCAGGGCTCGAACTC & & \\
\hline BMV2-F & $1086-1105$ & CTATAGCAAAGCGCTTTCGT & \multirow{2}{*}{$55^{\circ} \mathrm{C}$} & \multirow{2}{*}{798} \\
\hline BMV2-R & $1884-1864$ & CAAACGTAGGGCACACTAGGG & & \\
\hline BMVcp-F & $1213-1232$ & GATCTATGTCCTAATTCAGCG & \multirow{2}{*}{$55^{\circ} \mathrm{C}$} & \multirow{2}{*}{626} \\
\hline BMVcp-R & $1839-1819$ & CCAGTCAGGGGCTCTCCGAGC & & \\
\hline
\end{tabular}

*pozycja starterów odpowiednio dla BMV-Cz RNA1, RNA2, RNA3 (Ac. No.GU584131, GU584130 i GU584129) primer positions respectively for BMV-Cz RNA1, RNA2, RNA3 (Ac. No.GU584131, GU584130 and GU584129) 
$95^{\circ} \mathrm{C}$ przez $30 \mathrm{~s}$, przyłączanie starterów w $55^{\circ} \mathrm{C}$ przez $30 \mathrm{~s}$, elongacja w $72^{\circ} \mathrm{C}$ przez $60 \mathrm{~s}$ ) oraz elongacja końcowa w $72^{\circ} \mathrm{C}$ przez $10 \mathrm{~min}$. Produkty reakcji RT-PCR wizualizowano po elektroforezie $\mathrm{w} 1 \%$ żelu agarozowym $\mathrm{z}$ dodatkiem barwnika Midori Green (NIPPON Genetics Europe GmbH, Niemcy) w świetle UV. Specyficzność amplifikowanych fragmentów DNA potwierdzono poprzez sekwencjonowanie. Uzyskane produkty reakcji eluowano z żelu przy użyciu zestawu Wizard ${ }^{\circledR}$ SV Gel and PCR Clean-Up System firmy Promega (USA), zgodnie $\mathrm{z}$ procedurą zalecaną przez producenta. Sekwencjonowanie DNA zlecano firmie Genomed S.A. z Warszawy. Produkty reakcji RT-PCR sekwencjonowano w trzech powtórzeniach z użyciem specyficznych starterów stosowanych do reakcji RT-PCR. Analizę sekwencji wykonano przy zastosowaniu programu BioEdit (Hall 1999), natomiast porównanie sekwencji do danych zawartych w Banku Genów National Center for Biotechnology Information wykonano za pomocą programu BlastN (www.ncbi.nlm.nih.gov/blastn).

\section{Wyniki i dyskusja / Results and discussion}

Badanie infekcyjności wektorów jest jednym z elementów charakterystyki chorób wirusowych roślin. W opublikowanych pracach o tej tematyce wykorzystywano zarówno klasyczne metody zakażania zdrowych roślin wskaźnikowych przez wektory (Power i wsp. 1991; Mehner i wsp. 2003; Manurung i wsp. 2004), jak i molekularne techniki diagnostyczne (Canning i wsp. 1996; Ratti i wsp. 2004; Pospieszny i wsp. 2010; Strażyński i wsp. 2011; Gadiou i wsp. 2012). RT-PCR jest bardzo czułą i specyficzną techniką, która w przeciwieństwie do klasycznych metod, umożliwia szybkie wykrywanie i identyfikację wirusa bezpośrednio w wektorach.

Optymalizacja warunków reakcji RT-PCR z użyciem zaprojektowanych par starterów umożliwiła wykrywanie

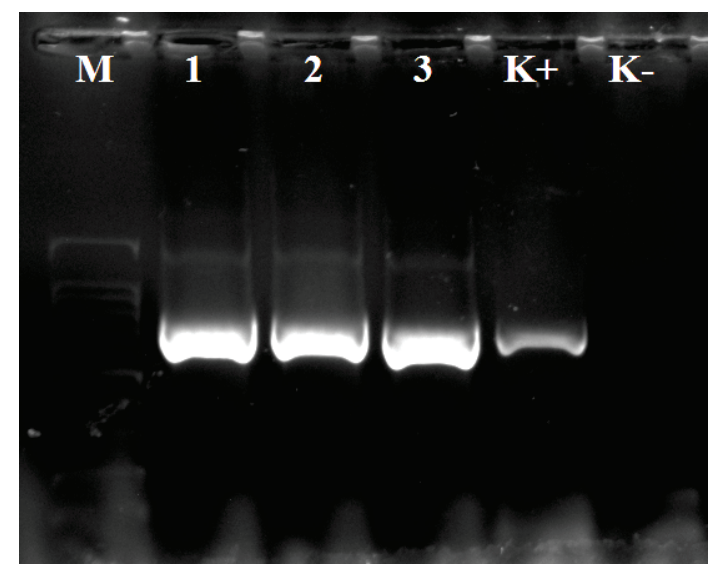

M - marker DNA Nova 100 bp DNA Ladder (Novazym), 1-3 - próby badane (RNA ze skrzypionek), K+ - kontrola pozytywna, K- - kontrola negatywna M - marker DNA Nova 100 bp DNA Ladder (Novazym), 1-3 - studied samples (RNA from beetles), K+ - positive control, K- - negative control

Rys. 1. Elektroforeza produktów RT-PCR z użyciem starterów BMV1-F/BMV1-R na $1 \%$ żelu agarozowym

Fig. 1. Electrophoresis mobility of RT-PCR products with BMV1-F/BMV1-R on $1 \%$ agarose gel

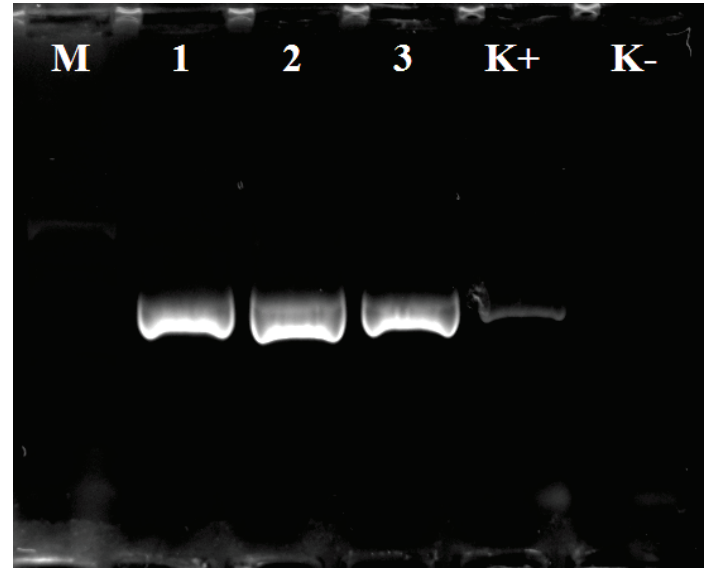

M - marker DNA Nova 100 bp DNA Ladder (Novazym), 1-3 - próby badane (RNA ze skrzypionek), K+ - kontrola pozytywna, K- - kontrola negatywna M - marker DNA Nova 100 bp DNA Ladder (Novazym), 1-3 - studied samples (RNA from beetles), K+ - positive control, K- - negative control

Rys. 2. Elektroforeza produktów RT-PCR z użyciem starterów BMV2-F/BMV2-R na 1\% żelu agarozowym

Fig. 2. Electrophoresis mobility of RT-PCR products with BMV2-F/BMV2-R on $1 \%$ agarose gel

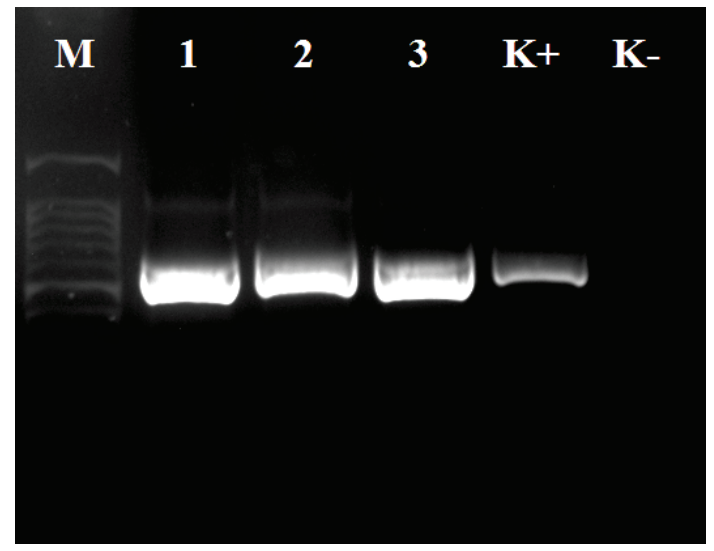

M - marker DNA Nova 100 bp DNA Ladder (Novazym), 1-3 - próby badane (RNA ze skrzypionek), K+ - kontrola pozytywna, K- - kontrola negatywna M - marker DNA Nova 100 bp DNA Ladder (Novazym), 1-3 - studied samples (RNA from beetles), $\mathrm{K}+-$ positive control, $\mathrm{K}-$ - negative control

Rys. 3. Elektroforeza produktów RT-PCR z użyciem starterów BMVcp-F/BMVcp-R na $1 \%$ żelu agarozowym

Fig. 3. Electrophoresis mobility of RT-PCR products with BMVcp-F/BMVcp-R on 1\% agarose gel

polskiego izolatu BMV-Sr w pojedynczych osobnikach skrzypionki zbożowej. Pozytywny wynik reakcji RT-PCR otrzymano dla wszystkich testowanych prób całkowitego RNA wyizolowanego z pojedynczych osobników skrzypionek, które żerowały na jęczmieniu porażonym przez BMV-Sr. Rozdział elektroforetyczny ujawnił obecność specyficznych produktów o przewidywanej wielkości: 830, 798 i 626 pz (rys. 1, 2, 3). Sekwencjonowanie DNA potwierdziło wirusowy charakter otrzymanych produktów reakcji RT-PCR. Odczytane sekwencje nukleotydów poszczególnych produktów uzyskanych ze starterami BMV1F/BMV1R, BMV2F/R i BMVcpF/R były identyczne $\mathrm{z}$ sekwencjami nukleotydów odpowiadającym im fragmentom RNA1 (KP137564), RNA2 (KP137565) i RNA4 (KP096132) BMV-Sr. 


\section{Wnioski / Conclusions}

1. Wykazano przydatność techniki RT-PCR do wykrywania BMV w skrzypionkach.

2. Opracowana technika może być wykorzystywana w badaniach nad oceną infekcyjności odłowionych skrzypionek, co pozwoli oszacować realne zagrożenia wystąpienia choroby.

\section{Podziękowanie / Acknowledgements}

Autorki przekazują serdeczne podziękowania prof. dr hab. Henrykowi Pospiesznemu z Instytutu Ochrony Roślin - Państwowego Instytutu Badawczego za zebranie prób kukurydzy porażonej przez BMV (BMV-Sr) oraz mgr Wiktorii Szydło z Uniwersytetu im. Adama Mickiewicza za pomoc w pracach ze skrzypionkami.

\section{Literatura / References}

Canning E.S.G., Penrose M.J., Barker I., Coates D. 1996. Improved detection of barley yellow dwarf virus in single aphids using RTPCR. Journal of Virological Methods 56: 191-197.

Daamen R.A., Stol W. 1993. Surveys of cereal diseases and pests in the Netherlands. Occurrence of insect pests in winter wheat. Netherlands Journal of Plant Pathology 99: 51-56.

Gadiou S., Ripl J., Jaňourová B., Jarošová J., Kundu J.K. 2012. Real-time PCR assay for the discrimination and quantification of wheat and barley strains of Wheat dwarf virus. Virus Genes 44: 349-355.

Hall T.A. 1999. BioEdit: a user-friendly biological sequence alignment editor and analysis program for Windows 95/98/NT. Nucleic Acids Symposium Series 41: 95-98.

http://frodo.wi.mit.edu/primer3 [Accessed: 10.11.2014].

Jeżewska M., Wieczorek M. 1999. Some properties of an isolate of Brome mosaic virus. Phytopathologia Polonica 17: 23-30.

Kostov K. 2001. Breeding wheat lines for host-plant resistance to cereal leaf beetle by using the cross mutation method. Bulgarian Journal of Agricultural Science 7: 7-14.

Lane L.C. 1977. Brome mosaic virus. CMI/AAB. Description of Plant Viruses, No. 180, (No. 3 revised), 4 pp.

Manurung B., Witsack W., Mehner S., Grüntzig M., Fuchs E. 2004. The epidemiology of Wheat dwarf virus in relation to occurence of the leafhopper Psammotettix alienus in Middle-Germany. Virus Research 100: 109-113.

Mehner S., Manurung B., Grüntzig M., Habekuss A., Witsack W., Fuchs E. 2003. Investigations into the ecology of the Wheat dwarf virus (WDV) in Saxony-Anhalt, Germany. Journal of Plant Disease and Protection 110 (4): 313-323.

Mise K., Pocsai E. 2004. Brome mosaic. p. 735-739. In: "Viruses and Virus Diseases of Poaceae (Gramineae)" (H. Lapierre, P.A. Signoret, eds.). INRA, Paris, 857 pp.

Pocsai E. 1987. Effect of brome mosaic virus infection of the plant height and weight of cereals at their early stages of growth. Cereal Research Communication 15 (2-3): 167-174.

Pospieszny H., Budziszewska M., Hasiów-Jaroszewska B., Obrępalska-Stęplowska A., Borodynko N. 2010. Biological and molecular characterization of Polish isolates of Tomato torrado virus. Journal of Phytopathology 158: 56-62.

Power A.G., Seaman A.J., Gray S.M. 1991. Aphid transmission of barley yellow dwarf virus: Inoculation access periods and epidemiological implications. Phytopathology 81 (5): 545-548.

Ratti C., Budge G., Ward L., Clover G., Rubies-Autonell C., Henry C. 2004. Detection and relative quantitation of Soil-borne cereal mosaic virus (SBCMV) and Polymyxa graminis in winter wheat using real-time PCR (TaqMan $\left.{ }^{\circledR}\right)$. Journal of Virological Methods 122: 95-103.

Rosen S., Skaletski H.J. 2000. Primer3 on the WWW for general use and for biologist programmers. p. 365-386. In: "Bioinformatics Methods and Protocols: Method in Molecular Biology" (S. Krawetz, S. Misenes, eds.). Totowa/New Jersey, Humana Press, 500 pp.

Stilmant D. 1995. Population dynamics of cereal leaf beetles, Oulema melanopus L. and O. lichenis Voet (Coleoptera: Chrysomelidae), on wheat fields in southern Belgium. Belgian Journal of Zoology 125: 199-205.

Strażyński P., Ruszkowska M., Jeżewska M., Trzmiel K. 2011. Evaluation of the autumn infection of winter barley with barley yellow dwarf viruses transmitted by anholocyclic forms of bird cherry-oat aphid Rhopalosiphum padi L. in Poland. Journal of Plant Protection Research 51 (3): 314-321.

Szabolcs J., Gáborjányi R. 1991. Brome mosaic virus transmission by cereal leaf beetle (Oulema melanopus, Coleoptera, Chrysomelidae). Acta Phytopathologica et Entomologica Hungarica 26 (1-2): 203-206.

Trzmiel K., Szydło W., Zarzyńska-Nowak A., Jeżewska M. 2015. First report of Brome mosaic virus (BMV) and Wheat streak mosaic virus (WSMV) co-infection in triticale plants in Poland. Plant Disease 99 (9), p. 1290.

Trzmiel K., Zarzyńska-Nowak A., Lewandowska M., Szydło W. 2015. Identification of new Brome mosaic virus (BMV) isolates systemically infecting Vigna unguiculata L. European Journal of Plant Pathology, nieopublikowane.

Ulrich W., Czarnecki A., Kruszynski T. 2004. Occurrence of pest species of the genus Oulema (Coleoptera: Chrysomelidae) in cereal fields in Northern Poland. Electronic Journal of Polish Agricultural Universities 7 (1), p. 4.

Walczak F., Babilas W., Piekarczyk K., Małachowska D., Lewartowski R., Kagan F., Grajek E., Melosik A., Grendowicz L., Romankow-Żmudowska A. 1987. Stan fitosanitarny roślin uprawnych w Polsce w 1986 roku i spodziewane wystąpienie agrofagów w 1987 roku. Broszura upowszechnieniowa. Instytut Ochrony Roślin, Poznań, p. 9.

Walczak F., Mrówczyński M., Wachowiak H. 1999. Skrzypionki zbożowe i ich zwalczanie. Ochrona Roślin 6: 10-12.

Wilson M.C., Treece R.E., Shade R.E. 1969. Impact of cereal leaf beetle larvae on yields of oats. Journal of Economic Entomology 62: 699-702.

www.ncbi.nlm.nih.gov/blastn [Accessed: 10.11.2014]. 